\title{
Elastic Modulus of Tangkin as the Indigenous Woven Back Pack from Dayak People in West Kalimantan
}

\begin{abstract}
N Masta
Physics Education Program, Faculty of Teacher Training and Education,

Universitas Kristen Indonesia, Jakarta, Indonesia

ngia.masta@uki.ac.id

ABSTRACT

Tangkin is an indigenous woven bag produced by Dayak tribe in West Kalimantan, which usually used to carry heavy luggage from forest garden to take home and vice versa. This paper aims to predict the elasticity modulus of Tangkin and identify factors which influenced it. Modulus elasticity reduced from Hooke's Law experiment, by using tensile test method, pulled by external force from $5.0-40 \mathrm{~N}$. There is three Tangkin's miniature assessed. They are made from bamboo, brace-less configuration, and have typical pattern of woven for each other. The pattern of woven has alliance with finite geometric series mathematics method by using Math Lab. The stress-strain graph presented the elasticity characterisation of Tangkin is still in Hooke's Law area. Tangkin's elastic modulus tends to increase in longer height of cylinder-like, but decrease on larger surface area. It means the toughness Tangkin will obtained with skinny but long shape. The elastic modulus value of Tangkin 1, Tangkin 2, and Tangkin 3 equal to 5909.1 Pa, 5267.4 Pa and 4550.8 Pa respectively. The weave pattern also influenced the elastic modulus, due to the force distribute direction. The pattern that have tendency to direct the force distribution oppositely from gravitational direction, will increase the strength of Tangkin. Meanwhile the slope of direction of force distribution will twisted the tangkin. This research can be useful for stage manage the alternative elasticity practical based on indigenous physics.
\end{abstract}

Keywords: indigenous physics, dayak, elasticity modulus, tensile test

\section{INTRODUCTION}

The craftsmen have made several modifications to enhance the toughness of Tangkin, among other are: bracing the cylinder with strong wood, rattan or bamboo, modify the woven, based the bottom side by wood, and adding the ring brace at the upper circle of cylinder-like woven with rattan. All material's component belongs to strong natural fibre, which has excellent mechanical properties. It is strong, tough and resilient. The overall statement above correlated to the elasticity properties.

The elasticity properties can be evaluated by tensile test, which can evaluated the deformation changing by giving external pulled force, moreover to break point. The tensile test is easy to use and easy to understand, even for middle level of education. Moreover, this method is commonly used for elasticity modulus characterization, especially fibre based material.

\section{MATERIAL AND METHODS}

This research aims to evaluate the elasticity properties of Tangkin, an indigenous backpack from Dayak tribe, West Kalimantan, Indonesia. There are three Tangkin that are evaluated in this research was made from bamboo, handmade plaited and supplied directly from Bengkayang Regency. The experiment was held in Physics Laboratory of Universitas Kristen Indondesia. Tensile test is analogue with the behavior of Tangkin when it's applied by the weight force from luggage inside. When the external pulled force applied to one side of Tangkin, the reaction force will produced in the whole tangkin sleeve, by the opposite direction. For tensile test conventional, the experiment was doing until the break point, but in this experiment, we are only applied Tangkin with limited force. It is due to the preservation of Tangkin shape from damage, considering our difficulties to bring it and preserved for the next experiment. 


\section{Preparation}

The experiment conducted tensile test method, applied Tangkin analogue as a single spring, pulled at the top or the bottom side. As a starting, every Tangkin has been measured in length and mass. The experiment instrument set (Figure 1) before it's pulled down by cylinder load from 5,450-30,45 N. at the cylinder edge, meanwhile the base side were hooked to the short stative. For each Tangkin in this experiment has no sling, composed only of a cylinder-like bamboo woven, and for each Tangkin have typically pattern woven. The pattern has been analysed by using force resultant and geometry series concept.

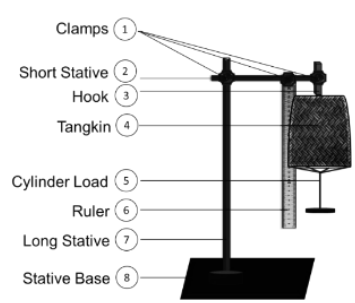

Figure 1: Experiment Set of Tangkin Tensile Test

\section{Tensile Test}

Tensile test described the deformation of object under external pulled force it has the same condition with the pulled force from the weight. Tensile test evaluated the gradient between stress and strain, which is elasticity modulus (Eq 1).

$$
E=\frac{\sigma}{e}=\frac{F}{\Delta L} \cdot \frac{L_{0}}{A}
$$

Elasticity modulus determined the preservation of a material to the object's shape or dimension. The less deformation changing (length, area and volume), increase the elasticity modulus. This ability of an object to preserved it's shape pointed to the stiffness of an object, which is pointed to the gradient between external force and length changing based on Hookes Law (Eq 2).

$$
k=\frac{F}{\Delta L}
$$

So does the Elasticity modulus is correlated with the stiffness. This Elasticity Modulus determined the toughness of an object. The stiffness (k) is linear correlation with elasticity modulus (E) (Eq.3).

$$
E=k \frac{L_{0}}{A}
$$

Briefly, if the stiffness increased, so does the elasticity modulus. The elasticity modulus of an object has been generally summarized in a general equation (Eq. 4)

$$
E^{c}=\left(\eta_{1} \eta_{0} E^{f} V^{f}\right)+\left(\gamma E^{m}\left(1-V^{f}\right)\right)
$$

With $E^{c}=$ composite elasticity Modulus, $E^{f}=$ fiber elasticity Modulus, $\eta_{1}=$ fibre length factor, $\eta_{0}=$ fibre orientation factor, $\gamma=$ Efficiency matrix factor; $V^{f}=$ fibre fraction volume. In this research limited only with describing the group of pattern configuration and the force distribution from Tangkin 1, Tangkin 2, and Tangkin 3. The strength factor such as , $\eta_{1}, \eta_{0}, \gamma$, and, $\gamma$ will not be detailed in this paper.

\section{Woven Geometric Analysis}

The bamboo woven pattern has a finite sum, so it is a convergent series. The final sentence of a caption must end with a period, so the partial sum defined as:

$$
S_{n}=a_{1}+a_{2}+\cdots+a_{n}
$$

With $\mathrm{n}=$ the number of terms. The woven can be break down into some parts, into each periodic group $\mathbb{G}$. When one cross sectional area has been pulled up due to gravitation force, both of stresses and strains are transformed and distributed according to the translational symmetry transformation of group $\mathbb{G}$. The displacement that occurs in each bamboo slats woven are also transformed similarly as the strains, due to the similar nature with strains. Hence it is induces the relation between woven pattern and relative displacement of group $\mathbb{G}$ (Abu Bakar, Kramer, Bordas, \& Rabczuk, 2013).

\section{RESULTS AND DISCUSSION}

This house tools could carry a heavyweight load $(\geq 50 \mathrm{~N})$. This amaze ability provide from the elasticity properties, which determined by Elasticity Modulus or Young Modulus.

\section{Tangkin Diagram}

Tangkin's configuration is a cylinder-like container equipped with single sling (Figure 2). The top side is open circle shape, while the bottom side is closed-square as the base. Generally, Tangkin devided in two parts, the cylinder like bowl and single sling. The sling, which only found at one side Figure 2(b), utilized to hang at the shoulders or head. The cylinder like-bowl of Tangkin in this study made from bamboo woven. This research study Tangkin without the sling. 


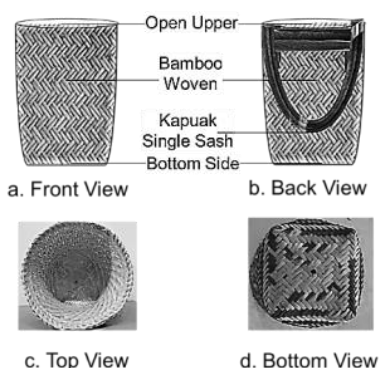

Figure 2: Tangkin Appearance; (a) Front view; (b) Back View; (c) Top View; (d) Bottom View.

The shape of Tangkin similarly with Tengkalang from Anak Dalam tribe (Jumiati, Hariyadi, \& Murni, 2012), a cylinder with smaller base than upper side. The difference between Tangkin and Tengkalang has been showed from the rare woven pattern.

Table 1: Mass and Geometry Dimensions Measurement of Tangkin

\begin{tabular}{|c|c|c|c|}
\hline Tangkin & $\begin{array}{c}\text { Upper-cross } \\
\text { sectional Area } \\
\left(\mathrm{m}^{2}\right)\end{array}$ & Height $(\mathrm{m})$ & Mass $(\mathrm{kg})$ \\
\hline 1 & $2,41 \times 10^{-2}$ & $1,35 \times 10^{-1}$ & $4,60 \times 10^{-2}$ \\
\hline 2 & $2,27 \times 10^{-2}$ & $1,30 \times 10^{-1}$ & $4,40 \times 10^{-2}$ \\
\hline 3 & $2,41 \times 10^{-2}$ & $1,25 \times 10^{-1}$ & $4,30 \times 10^{-2}$ \\
\hline
\end{tabular}

The actual Tangkin could be three or ten times greater than this miniature. However, this measure can still be used as a model for conducting experiments in determining the actual elastic modulus of Tangkin.

\section{Analysis of Tangkin's Weave Pattern}

The woven pattern is the type of materials component plaited, with intention to strengthen the materials. The woven pattern has generator inserted properties $\left(\sigma_{i}\right)$ in every node meeting of woven, which strengthen the whole material structure (Ariswoyo \& Nasution, 2005).

Figure 3 show the pattern for all three evaluated Tangkins. The half part of Bamboo woven was coloured by natural dye to append the aesthetic value (Dwi Rahmawati Rusja, Pancaning Wardoyo, \& Riza Linda, 2018).

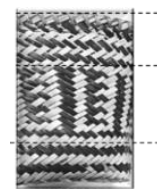

(a)

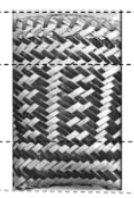

(b)

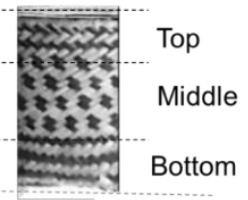

(c)
Figure 3: Woven Pattern of Tangkin (a) Tangkin 1; (b) Tangkin 2; (c) Tangkin 3

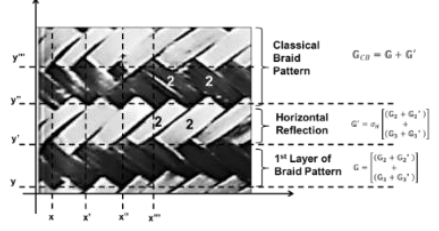

Figure 4: Balanced Twill-like on Braid Woven Pattern configuration of up and low side of all three Tangkin

Woven patterns at the top and bottom has been given in Figure 4, which can be shown as a group of braided hair, therefore this pattern is usually determined as braid pattern. It is marked by cross-tight webbing with $2 \times 2$ matrices order which forms a parallelogram and has two folding symmetries. The pattern has the same similarity with Liris pattern from Osing tribe from jawa timur (Fajar, F. A., Sunardi, S., \& Yudianto, 2018), Kelerai Siku Keluang pattern from North Kalimantan (Abu Bakar et al., 2013), and bilik pattern or kepang pattern from Bali (Prasasti, 2018) and Central Java (Prasasti, 2018). This pattern also has the same pattern with balanced twill weaving, which is used in making jeans, gabardin, and denim (Adumitroaie \& Barbero, 2011a) (Adumitroaie \& Barbero, 2011b) (Cherif, Poilâne, Vivet, Ben Doudou, \& Chen, 2016). This woven pattern has been used to reinforced the fabrics strength, and the proposed geometrical model of this pattern has been intended as the foundation of numerical modeling mecchanical properties (Adumitroaie \& Barbero, 2011a).

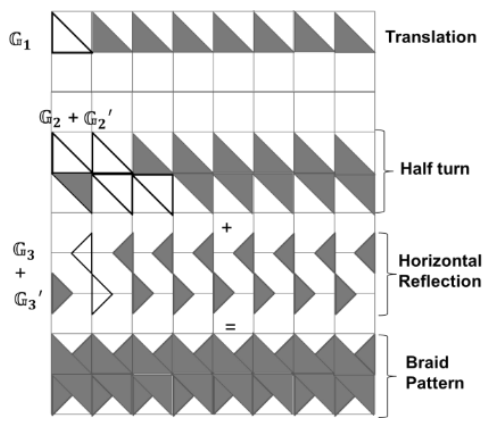

Figure 5: Woven Pattern of up and low side of Tangkin

The woven pattern built from the initial pattern and continued along the plane under translational invariance given by Eq (6), by assumed the curved is parameterized consistently. Term $2 L$ determined the period of one turn $(2 \pi)$, indicated by one full lap trajectory as the lower limit and final limit $[-L, L]$.

$$
c(t)=r(t+2 l)
$$




$$
\begin{aligned}
& =(x(t+2 L), y(t+2 L)) \\
& =(x(t)+K, y(t))
\end{aligned}
$$

For each $x$ and $y$ function can be devided into odd and even function, show the decomposed function.

$$
\begin{aligned}
x(t) & =x_{o}(t)+x_{e}(t) \\
& =\frac{x(t)+x(-t)}{2}+\frac{x(t)-x(t)}{2} \\
y(t) & =y_{o}(t)+y_{e}(t) \\
& =\frac{y(t)+y(-t)}{2}+\frac{y(t)-y(t)}{2}
\end{aligned}
$$

The term $\mathbb{G}_{2}$ symmetry equation filled by:

$$
\begin{aligned}
x(-t), y(-t) & =(-x(t),-y(t)) \\
& =\rho(x(t), y(t))
\end{aligned}
$$

With $\rho$ describe the symmetries of half-turn from origin. The term $\mathbb{G}_{2}$ symmetry identification done by testing the even function, if the even function is zero, then the term $\mathbb{G}_{2}$ is symmetry under origin. The term $\mathbb{G}_{3}$ symmetry in this pattern fulfilled with

$$
\begin{aligned}
x(-t), y(-t) & =(x(t),-y(t)) \\
& =\frac{1}{2} \sigma_{h}(x(t), y(t))
\end{aligned}
$$

With $\frac{1}{2} \sigma_{h}$ describe the symmetries of horizontal mirror, factor $\frac{1}{2}$ noted the half transformation from $\mathbb{G}_{1}$ geometry dimension. Since braid pattern consist of the combination of $\mathbb{G}_{2}+\mathbb{G}_{2}{ }^{\prime}$ and $\mathbb{G}_{3}+\mathbb{G}_{3}{ }^{\prime}$, then $\mathbb{G}_{2}{ }^{\prime}$ and $\mathbb{G}_{3}{ }^{\prime}$ also must be defined. The term $\mathbb{G}_{2}{ }^{\prime}$ defined as group $\mathbb{G}_{2}$ that has been translation for half $\ell$ on $x$ axis, then $\mathbb{G}_{2}{ }^{\prime}$ filled by:

$$
\begin{aligned}
x(-t), y(-t) & =\left(-x(t)+\frac{1}{2} K,-y(t)\right) \\
& =\rho\left(\left(\frac{1}{2} \tau(x(t))\right), y(t)\right)
\end{aligned}
$$

The term $\mathbb{G}_{3}{ }^{\prime}$ determined the group $\mathbb{G}_{3}$ that has been vertically reflected and has been translation transformated for one $\ell$ on $y$ axis, then $\mathbb{G}_{3}{ }^{\prime}$ filled by:

$$
\begin{aligned}
x(-t), y(-t) & =(x(t),-y(t)) \\
& =\sigma_{v}\left[\frac{1}{2} \sigma_{h}[-x(t),[\tau .(y(t)\right.
\end{aligned}
$$

The classical braid pattern at the top and the bottom part of all three tangkin (Figure 5) configured of a bunch of pairing grup $\left(\mathbb{G}+\mathbb{G}^{\prime}\right)$, which $\mathbb{G}^{\prime}$ denoted as $\mathbb{G}^{\prime}=\sigma_{H}[\mathbb{G}]$. This group pair assembled periodically and full-filled the part of top and bottom of Tangkin, for about 2-3 cm length.

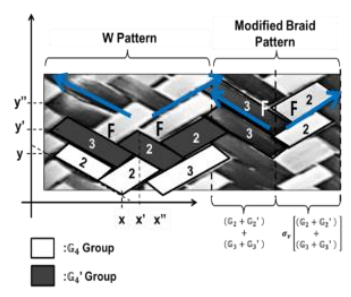

Figure 6: Weave configuration at middle part of cylindrical sleeve of Tangkin 1

Meanwhile the middle part of Tangkin 1 appeared a number modification of braid pattern (Figure 6), it has W pattern and modified braid pattern criss-cross each other. Tangkin 1 middle part pattern showing the Modified Braid Pattern, which show by the $3 \times 2$ matrice, while the classical braid pattern is stated by $2 \times 2$. The pair group of $\mathbb{G}$ on tangkin 1 middle part also appeared by vertical reflection $\left(\sigma_{v}\right)$, meanwhile the Figure 5 show the horizontally reflection $\left(\sigma_{H}\right)$. On the left side of Modified braid pattern show the W pattern, which has the analogue appearance with the letter of $\mathrm{W}$. The $\mathrm{W}$ pattern has a semblance apparition with modified braid pattern, it is exhibit the extension of $3 \times$ 2 matrice pattern and continue with 2 . Therefore, Tangkin 1 pattern can be represented as $3 \times 2 \times 2$ matrice. The intended of forced distribution can be determined by weave pattern. Middle part of Tangkin 1 show the $W$ pattern pointed on one vertically line, likewise the modified braid pattern.

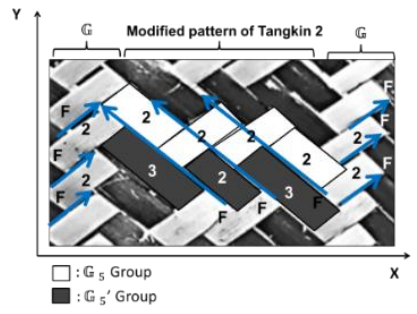

Figure 7: Weave Pattern of Tangkin 2

Figure 7 show the weave pattern of middle part of Tangkin 2, which contributed with classical braid pattern and modified pattern. The modified pattern consists of $\mathbb{G}_{5}$ and $\mathbb{G}_{5}{ }^{\prime}$ term of group. The term $\mathbb{G}_{5}$ represented as $2 \times 2 \times 2 \times 2$, meanwhile the $\mathbb{G}_{5}{ }^{\prime}$ represented as $3 \times 2 \times 3$. Modified pattern around by classical braid pattern with $\mathbb{G}_{5}$ and $\mathbb{G}_{5}{ }^{\prime}$ group pattern as a pair, criss-crossed each other at $y$ axis. This pattern has a similarity with $W$ pattern, but has longer row and has only single braid $(\mathbb{G})$ pattern as a border. Term of $\mathbb{G}$ periodically repeat at $Y$ axis, meanwhile the modified pattern of Tangkin 2 repeated periodically at $X$ axis. The blue line show the intended of Force $(\mathrm{F})$, that caused by the pulled of gravity on tensile test. The 
longer line show the greater value of a pulled force. Force headed on one direction, dominated by the modified pattern of Tangkin 2. Meanwhile the $\mathbb{G}$ pattern directed on vertically reflection with the modified pattern of Tangkin 2 .

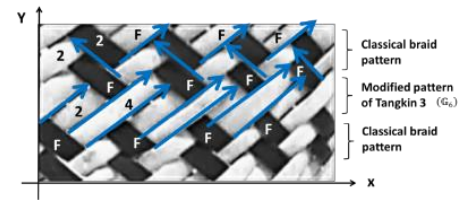

Figure 8: Woven Pattern of Tangkin 3.

The weave pattern of Tangkin 3 middle part shown by Figure 8, this pattern consist of classical braid pattern $(\mathbb{G})$ and modified pattern of Tangkin $3\left(\mathbb{G}_{6}\right)$. Both pattern $\mathbb{G}_{\text {and }} \mathbb{G}_{6}$ located intermittently side by side. The classical braid pattern stated by $2 \times 2$ matrice layered criss-crossed with modified pattern of Tangkin 3 along $Y$ axis. The term $\mathbb{G}_{6}$ stated with $2 \times 4$ matrices, force distribution $(F)$ of these matrices direct in one head cross lined with $\mathbb{G}$ pattern. The braid pattern has two head cross line, which one is in the same direction with $\mathbb{G}_{6}$ and the other is in vertically reflected direction. From the description above show the force distributed tend to the same direction with $\mathbb{G}_{6}$. The pattern of modified pattern of Tangkin $3\left(\mathbb{G}_{6}\right)$ has no border, which show in Tangkin 1 (Figure 7) and Tangkin 2 (Figure 8) weave pattern. This unique characteristic caused the force direction distribution were dominantly determined by the direction of $\mathbb{G}_{6}$. This properties affect the tends of mechanical distortion of Tangkin 3 weave pattern, it is easily to be splitting or twisted in the same tend to $\mathbb{G}_{6}$.

\section{Elasticity Modulus of Tangkin}

Studies about elastic modulus testing nowadays have been widely applied, such as biomaterials especially for medical purposes ( $\mathrm{Lu}$ et al., 2015); microstructural engineering (Chen, Wang, Giuliani, \& Atkinson, 2015), also mining, petroleum, and industries (Madhubabu et al., 2016).

Figure 9 describe the relationship between strain and stress of Tangkin, this graphs show all three tangkin still in obedience with Hooke's Law. Tangkin 1 has the largest elasticity modulus and the smallest show from Tangkin 3. Tangkin 1 and 3 has the same upper-cross sectional area, but different in height of cylinder-like bowl. The elasticity modulus can be affect the with initial length (height) of weave sleeve. The increment of initial length will increase the elasticity modulus. Even so, their value of elastic modulus from all three tangkin shows the similarity, it is in the range $5 \times 10^{3} \mathrm{~Pa}$. This similarity may caused by the same pattern at the top and bottom part (Figure 4). The similarity in these weave pattern makes the pulled force prevalent distributed along $Y$ axis on weave sleeve surface, in the opposite direction with gravitational force.

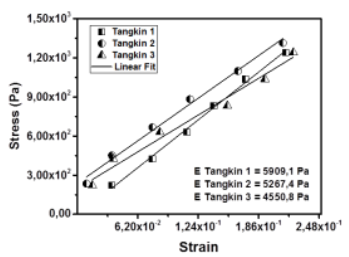

Figure 9: Elasticity Modulus of Tangkin.

The affects analysis of weave pattern for each elastic modulus of Tangkin also appeared in Tangkin 1, which has the highest value of elastic modulus. It is due to the weave pattern of middle part, which show the tendency to focus the pulled force to the opposite direction with gravitational force (Figure 6). The straight line direction of force caused the tangkin sleeve tend to maintain it's shape from the deformation, during the external forced applied. This ability makes all pattern in Tangkin 1 still in linear position and not twisted easily.

The experiment set is easy to find and also simply to be arranged. The utilization of weave pattern have been applied in mathematics and science learning process, it increased the creative ability (Ndeo et al., 2018). It is contextual to the local wisdom, it caused boost the student motivation to active in learning process (Ndeo et al., 2018). This research can be used as a model of indigenous physics experiment, chiefly in Elastic Properties Examination.

\section{CONCLUSION}

In this work, the elastic modulus of three tangkin miniature were have been examined by using tensile test. The elastic modulus of Tangkin 1, Tangkin 2, and Tangkin 3 equal to 5909,1 $\mathrm{Pa}, 5267,4 \mathrm{~Pa}$ and 4550,8 $\mathrm{Pa}$ respectively. The elastic modulus affected by geometry dimension and the pattern of weave. The weave pattern determined the force distribution in the whole weave sleeve. The force distribution influence the ability of tangkin to maintain it's shape. If the force distribution directed as the straight line with a certain slope, then the value of slope will affected the twisted able properties. The simple, easy to find and this affordable experiment method in this paper can be used to teaching physic with indigenous physics approach. 


\section{ACKNOWLEDGMENTS}

This work was financially sponsored by Universitas Kristen Indonesia.

\section{REFERENCES}

[1] Abu Bakar, I. A., Kramer, O., Bordas, S., \& Rabczuk, T. (2013). Optimization of elastic properties and weaving patterns of woven composites. Composite Structures, 100, 575-591. https://doi.org/10.1016/j.compstruct.2012.12.043

[2] Adumitroaie, A., \& Barbero, E. J. (2011a). Beyond plain weave fabrics - I. geometrical model. Composite Structures, 93(5), 1424-1432. https://doi.org/10.1016/j.compstruct.2010.11.014

[3] Adumitroaie, A., \& Barbero, E. J. (2011b). Beyond plain weave fabrics - II. Mechanical properties. Composite Structures, 93(5), 1449-1462. https://doi.org/10.1016/j.compstruct.2010.11.016

[4] Ariswoyo, S., \& Nasution, M. K. (2005). Pemahaman Diskrit dalam Teori Grup Melalui Teori Anyaman. Al-Khawarizmi: Journal of Computer Science, $\quad l(3)$, 85-91. https://doi.org/10.13140/RG.2.2.28935.14248

[5] Chen, Z., Wang, X., Giuliani, F., \& Atkinson, A. (2015). Microstructural characteristics and elastic modulus of porous solids. Acta Materialia, 89, 268277. https://doi.org/10.1016/j.actamat.2015.02.014

[6] Cherif, Z. E., Poilâne, C., Vivet, A., Ben Doudou, B., \& Chen, J. (2016). About optimal architecture of plant fibre textile composite for mechanical and sorption properties. Composite Structures, 140, 240-251. https://doi.org/10.1016/j.compstruct.2015.12.030

[7] Dwi Rahmawati Rusja, Pancaning Wardoyo, E. R., \& Riza Linda. (2018). Pemanfaatan Tumbuhan Sebagai Pewarna Alami Oleh Suku Dayak Randu Di Desa Suka Damai Kabupaten Melawi. Protobiont, 7(1), 13-19.

[8] Fajar, F. A., Sunardi, S., \& Yudianto, E. (2018). Etnomatematika Pembuatan Kerajinan Tangan Anyaman Bambu Masyarakat Osing Di Desa Gintangan Banyuwangi Sebagai Bahan Ajar Geometri. KadikmA, 9(3), 97-108. https://doi.org/10.15036/arerugi.44.821_2

[9] Jumiati, Hariyadi, B., \& Murni, P. (2012). Studi Etnobotani Rotan Sebagai Bahan Kerajinan Anyaman Pada Suku Anak Dalam (SAD) di Dusun III Senami, Desa Jebak, Kabupaten Batanghari, Jambi. Biospecies, 5(1), 33-41.

[10] Lu, T., Wen, J., Qian, S., Cao, H., Ning, C., Pan, X., ... Chu, P. K. (2015). Enhanced osteointegration on tantalum-implanted polyetheretherketone surface with bone-like elastic modulus. Biomaterials, 51, 173-183. https://doi.org/10.1016/j.biomaterials.2015.02.018
[11] Madhubabu, N., Singh, P. K., Kainthola, A., Mahanta, B., Tripathy, A., \& Singh, T. N. (2016). Prediction of compressive strength and elastic modulus of carbonate rocks. Measurement: Journal of the International Measurement Confederation, 88 (September), 202-213. https://doi.org/10.1016/j.measurement.2016.03.050

[12] Ndeo, M. M., Lusia, C., Putri, B., Kurniawati, Y., Pendidikan, P., Universitas, M., \& Dharma, S. (2018). Kreatifitas Siswa Kelas VI SD dalam Mengenali Bentuk Geometris pada Anyaman Indonesia. Prosiding Seminar Nasional MIPA, 181186.

[13] Prasasti, I. (2018). Pemanfaatan Metode Iterated Function System Dalam Pengembangan Motif Anyaman. In Digital Repository Repository Universitas Jember. Retrieved from https://repository.unej.ac.id/handle/123456789/8739 4 